\title{
EXERCISE TOLERANCE AND PHYSICAL ACTIVITY IN CHILDREN WITH MOST COMMON CARDIOVASCULAR DISEASES
}

\author{
Shtrakh K., Rak L., Shevchenko N., Odigbo Shalom
}

\begin{abstract}
Summary: The cardiovascular system is actively involved in the adaptive reactions of the body. The deterioration of adaptive processes decreases the functional capabilities of the heart. Arterial hypertension is often known as the main cause of fatal cardiovascular events in adults. The aim of our study was to determine the adaptive capabilities of the cardiovascular system of adolescents with non-inflammatory cardiomyopathies depending on physical activity's level. There were examined 92 patients with arterial hypertension and connective tissue dysplasia, the mean age was $15,4 \pm 1,33$ years. In order to study tolerance to the minimum physical activity and its influence on the state of the cardiovascular system in children, the Ruffier test was conducted. The vegetative reactions of central nervous system were performed by the orthostatic test. The functional state of the myocardium was assessed according to the results of the ultrasonic Doppler study of the heart. As a result of the study, it was found that in connective tissue dysplasia and arterial hypertension adaptation mechanisms were affected, accompanied by a weakening of cardiac functional capabilities. This happens against the background of a decrease in the functioning of the left ventricle. These changes are accompanied by hyperactivation of the autonomic nervous system in patients in the studied groups. The physical activity and physical development of children affect the adaptive capabilities of a growing organism. This is due to the fact that the children in group with AH and CTD were less physically active than children without myocardial pathology. Adolescents who showed the reduced results of Ruffier's test and had regular sports sections need change of a mode of training and further inspection.
\end{abstract}

KEY WORDS: cardiovascular system, adaptation, physical activity, exercise tolerance, adolescents

\section{INFORMATION ABOUT AUTHOR}

Kateryna Shtrakh, assistant of the department of pediatric № 2, V. N.Karazin Kharkiv National University, 6, Svobody sq., Kharkiv, Ukraine, 61022, e-mail: shtrah@ @arazin.ua, ORCID ID: http://orcid.org/0000-0003-3563-0371

Larysa Rak, head of the Pediatric department of SI «Institute for children and adolescents health care of the NAMS of Ukraine», 52 a, Yuvileinyi Avenue, Kharkiv, Ukraine, 61153; professor of the pediatric department, V. N.Karazin Kharkiv National University, 6, Svobody sq. Kharkiv, Ukraine, 61022, e-mail: larisarakdoct@ukr.net, ORCID ID: https://orcid.org/0000-0001-9955-2638

Natalia Shevchenko, head of the pediatric department № 2, V. N.Karazin Kharkiv National University, 6, Svobody sq., Kharkiv, Ukraine, 61022; MD, leading research worker of Cardiorheumatology department of SI «Institute for children and adolescents health care of the NAMS of Ukraine», 61153, e-mail: natalia.shevchenko@karazin.ua, ORCID ID: https://orcid.org/0000-0003-4407-6050

Shalom Odigbo, student of 6 th course of medical faculty; V. N. Karazin Kharkiv National University, 6, Svobody sq., Kharkiv, Ukraine, 61022, e-mail: kwinshally8167@gmail.com, ORCID ID: https://orcid.org/0000-0002-4314-312X

\section{INTRODUCTION}

Recent findings have suggested that physical inactivity worsens the general health status of children and adolescents affected by several diseases. The cardiovascular system is involved in all the adaptive reactions of the body and a decrease in functional capabilities worsens the person's adaptation to activities and stress [1]. Adaptation to physical activity implies the development of functional changes of cardiovascular system. Exercise tolerance is the ability to perform exercise at the normally expected level, and a decreased tolerance is one of the first signs of an inadequate response of the oxygen transport systems, especially the cardiovascular [2].

Among the medical problems of the cardiovascular system, the leading place is occupied by arterial hypertension and atherosclerosis, which are the main causes of mortality in the modern population $[3,4]$. However, current studies indicate that the atherosclerotic process starts to develop in childhood. Arterial hypertension ( $\mathrm{AH})$ is a fatal problem caused by widespread prevalence and a high risk of vascular complications. Multiple risk factors contributing to CVD include 
obesity, high blood pressure, diabetes, aging, male sex, metabolic syndrome, and physical inactivity [5]. Lifestyle modifications are advocated for the prevention, treatment, and control of hypertension, with exercise being an integral component. Arrhythmias - is pathology in children could be triggered or exacerbated by exercise due to catecholamine release, increase in cardiac output, and electrolyte imbalance. Non-differentiated connective tissue dysplasia (CTD) is manifested most commonly with small abnormalities of heart development (SAHD) - abnormal chords of the ventricles, which have ectopic attachment, associated with mitral valve prolapse, development of myocardial ischemia $[5,6]$. The presence of this pathology can lead to impaired contractile and pumping function of the heart, and therefore lead to maladaptation of the cardiovascular system.

There have been many studies in the direction of clarifying the ways of development of dysfunction and myocardial pathology, introducing new methods of research [7, 8, 9]. These children are characterized by the discoordination of the autonomic regulation of respiratory and cardiovascular systems, a violation of the psycho-emotional status $[10,11]$.

Most children lead a hypodynamic lifestyle $[12,13]$. This is negatively affects the activity of the cardiovascular and nervous systems. Therefore, at a young age, it is necessary to study the relationship between physical activity and the reactions of the cardiovascular and autonomic nervous systems of children and adolescents in order to study the adaptive capabilities of the body.

The results of studies suggest that short-term exercise does not appear to reduce resting systolic and diastolic blood pressure in children and adolescents $[14,15,16]$.

Significant frequency of various heart rhythm disorders, SAHD, AH which are also associated with many cases of sudden cardiac death in young people and children, myocardial dysfunction, immunological changes [17, 18].

Therefore, it was necessary to study exercise tolerance as one of the components of the adaptive capacity of children with heart disease.

The aim of the study was to determine the adaptive capabilities of the cardiovascular system of adolescents with non-inflammatory cardiomyopathies depending on physical activity's level.

\section{MATERIALS AND METHODS}

There were examined 92 patients with noninflammatory myocardial diseases aged 13 to 18 years: 44 patients $(18,2 \%$ of girls and $81,8 \%$ of boys) with diagnosed AH I and II degree-first group; 48 children (26,7\% of girls and $73,3 \%$ of boys) with signs of CTD second group. There are 23 persons had cardiac arrhythmias in this groups. The control group included 20 practically healthy adolescents (6 girls and 14 boys) with the average age $15,4 \pm 1,33$ years.

The physical development of adolescents was assessed. Anthropometry was performed with the calculation of body mass index (BMI) [15]. The objective status was evaluated. The James-Edward Ruffier test was conducted to evaluate the functional status of the cardiovascular system. The Ruffier Squat Test is a simple cardiovascular endurance test which involves measuring heart rate before and after performing 30 squats in 45 seconds [16, 19, 20]. Patients were tested with the orthostatic test. Physical activity was assessed in accordance with the International Physical Activitiy Questionnaire (IPAQ) [21, 22, 23]. An ultrasound examination was used to study the structure and function of the heart in the $\langle\mathrm{M} »$ and $\langle\mathrm{B} »$ modes, as well as in the constant-wave and color scanning mode with a $5 \mathrm{MHz}$ convex sensor on the device digital ultrasound diagnostic system SA8000 Live (firm «Medison», Korea) according to the standard method recommended by the Ultrasound Diagnostic Association. Indicators such as diameter of aortic root (AR), left ventricular ejection fraction (EF), left ventricular stroke volume (SV), left ventricle minute volume (MV), left atrium (LA), right ventricle (RV) sizes, myocardial mass of the left ventricle $\left(\mathrm{MM}_{\mathrm{LV}}\right)$, posterior wall of the left ventricle relative thickness $\left(\mathrm{RTPW}_{\mathrm{LV}}\right)$, thickness of the interventricular septum (IVST), total peripheral resistance (TPR) were analyzed. All studies were conducted 2-3 days after hospitalization, under free regime, before treatment began. The collected data were stored in a database (Microsoft Excel 2003) and mean, standard deviation (SD), and correlation coefficient were calculated by using SPSS 17 to establish significance between the groups. The results were seen at $5 \%$ level of significance and $P$ value $<0.05$ was considered to be statistically significant. 


\section{RESULTS AND DISCUSSION}

Children in the group with $\mathrm{AH}$ made complaints in $90,1 \%$ cases, with CTD - in $84,0 \%$. In both groups the most common complaints were cephalgia, cardialgia, fatigue and weakness. In $2,3 \%$ of patients with CTD palpitations were increased after exercises, in $1,0 \%$, syncope were observed. All children in the control group did not make any complaints about their health.

The excessive body weight (BMI ranges from 23,5 to $27,5 \mathrm{~kg} / \mathrm{m}^{2}$ ) was found at $32,0 \%$ of patients with $\mathrm{AH}$. There was insufficient body weight in single cases. All children with CTD had a BMI within normal range (average BMI was $19,1 \pm 5,2 \mathrm{~kg} / \mathrm{m}^{2}$ ). Children in the control group had normal data $(19,9 \% \pm 0,4 \mathrm{~kg}$ $\left./ \mathrm{m}^{2}\right)$ and underweight $\left(16,6 \% \pm 0,6 \mathrm{~kg} / \mathrm{m}^{2}\right)$.

The average of systolic blood pressure in children with $\mathrm{AH}$ was $127,6 \pm 3,6 \mathrm{~mm}$. Hg. art., diastolic - 69,6 $\pm 1,9 \mathrm{~mm}$. Hg. art., the limitation of arterial hypertension - up to 1 year. Therefore, in group with CTD those averages were $107,7 \pm 2,3 \mathrm{~mm}$. $\mathrm{Hg}$. art. and $60,8 \pm 1,2 \mathrm{~mm} \mathrm{Hg}$ art. In control group the systolic blood pressure was 109,3 $\pm 3,7 \mathrm{~mm}$. Hg. art., diastolic $-60,8 \pm 1,6 \mathrm{~mm}$. Hg. art. In group with $\mathrm{AH}$ the averages of blood pressure were significantly higher $(\mathrm{p}<0,05)$.

ECG data showed the presence of sinus arrhythmias in $30,7 \%$ of patients with $\mathrm{AH}$ and $47,0 \%$ patients of the second group. There were tachyarrhythmia and bradyarrhythmia in equal parts. In $26,6 \%$ of patients with CTD defined the violation of repolarization. The results of ECG in all groups were clinically insignificant for comparison.
Ultrasound examination showed that the size of the heart chambers in adolescents with $\mathrm{AH}$ with reduced and normal exercise tolerance did not differ significantly. Only the myocardial mass of the left ventricle in children with normal exercise tolerance was higher than the index of children with reduced tolerance $(109 \pm 3,5$ against to $86,7 \pm 2,3 ; \mathrm{p}<0,01)$. The pumping function of the heart (stroke volume (SV), left ventricular ejection fraction) was not different. Adolescents with $\mathrm{AH}$ and excess body weight had larger SV $(94,9 \pm 10,1 \mathrm{ml}$; $\mathrm{p}<0,08)$ and higher minute blood volume $(6,2 \pm 0.5 \mathrm{ml} ; \mathrm{p}<0,01)$. In both groups, the objective status was satisfactory.

Only the diameter of left atrium in children with CTD and reduced exercise tolerance signifycantly was less that of children with normal tolerance $(p<0,01)$. Indicators of the pumping function of the heart (stroke volume $(\mathrm{SV})$, left ventricular ejection fraction $\left(\mathrm{EF}_{\mathrm{LV}}\right)$ ) did not differ.

When assessing the morphometric and hemodynamic characteristics of the heart, it can be noted that the dimensions of the right ventricle, aortic root, left atrium and the thickness of the interventricular septum were larger in the children of the group with $\mathrm{AH}$.

When examining hemodynamic parameters it should be noted that they were higher among children with CTD - total peripheral resistance of the heart (TPR) $-2082,0 \pm 143,9)$ than in the comparison $-1647,0 \pm 135,1$, indicating that in children with CTD, myocardial remodeling is compensatory.

Morphofunctional characteristics of the heart in patients with cardiovascular diseases depending on exercise tolerance (tab.).

Table

Morphofunctional characteristics of the heart in patients with cardiovascular diseases depending on exercise tolerance

\begin{tabular}{|c|c|c|c|c|}
\hline \multirow[t]{2}{*}{ Indicators } & \multicolumn{2}{|c|}{ Group with $\mathrm{AH}, \mathrm{n}=44$} & \multicolumn{2}{|c|}{ Group with CTD, $\mathrm{n}=30$} \\
\hline & $\begin{array}{c}\text { With reduced } \\
\text { exercise tolerance }\end{array}$ & $\begin{array}{l}\text { With satisfactory } \\
\text { exercise tolerance }\end{array}$ & $\begin{array}{c}\text { With reduced } \\
\text { exercise tolerance }\end{array}$ & $\begin{array}{l}\text { With satisfactory } \\
\text { exercise tolerance }\end{array}$ \\
\hline AR,sm. & $2,7 \pm 0,1$ & $2,7 \pm 0,06$ & $2,4 \pm 0,02 * *$ & $2,5 \pm 0,05^{*}$ \\
\hline LA,sm & $2,5 \pm 0,1$ & $2,5 \pm 0,1$ & $2,3 \pm 0,02 *$ & $2,4 \pm 0,03$ \\
\hline $\mathrm{RV}, \mathrm{sm}$. & $2,0 \pm 0,08$ & $2,0 \pm 0,06$ & $1,9 \pm 0,1$ & $1,7 \pm 0,06$ \\
\hline $\mathrm{RTPV}_{\mathrm{LV}}$ & $0,3 \pm 0,03$ & $0,27 \pm 0,02$ & $0,3 \pm 0,006$ & $0,2 \pm 0,008$ \\
\hline TIVS,sm. & $0,7 \pm 0,02$ & $0,7 \pm 0,03$ & $0,6 \pm 0,09$ & $0,6 \pm 0,01$ \\
\hline MMLV,g. & $86,7 \pm 2,3$ & $109,0 \pm 3,5^{*}$ & $80,4 \pm 5,6$ & $78,2 \pm 3,6$ \\
\hline EFlv, \% & $70,1 \pm 2,1$ & $68,9 \pm 2,5$ & $70,3 \pm 1,1$ & $68,0 \pm 1,5$ \\
\hline $\mathrm{MV}, 1 / \mathrm{min}$. & $4,7 \pm 0,3$ & $4,7 \pm 0,4$ & $3,8 \pm 0,3$ & $3,3 \pm 0,2$ \\
\hline $\mathrm{SV}, \mathrm{ml}$ & $71,4 \pm 4,8$ & $76,4 \pm 7,9$ & $58,3 \pm 4,7$ & $59,0 \pm 3,0$ \\
\hline TPR,Pa*sec/ml & $1647,0 \pm 135,1$ & $1602,0 \pm 87,9$ & $2082,0 \pm 143,9$ & $1898,7 \pm 176,7$ \\
\hline
\end{tabular}

Note: $* *-p<0.001 ; *-p<0.05$; when compared with similar indicators of the control group. 
Small structural abnormalities of the heart were found in $100,0 \%$ cases with CTD, as signs of connective tissue dysplasia: the prolapse of mitral valve prolapse (MVP) I degree $(70,2 \pm 1,1 \%)$, which were accompanied by grade I regurgitation $(5,2 \pm 0,8 \%)$ and grade II pansystolic regurgitation $(3,5 \pm 0,5 \%)$. In children with $\mathrm{AH}$ in $50,1 \%$ cases was observed unstable and grade I prolapse of mitral valve without regurgitation. All patients with CTD and half patients with $\mathrm{AH}$ had false chords localized in the left ventricle.

To clarify tolerance and physical activity of the children, questionnaires were conducted and functional tests were performed.

Exercise tolerance by the Ruffier test was satisfactory in $47,2 \%$ of children with cardiovascular disorders. In $52,8 \%$ of them results were weak and unsatisfactory. Decreased exercise tolerance was observed in $47,6 \%$ of children with $\mathrm{AH}$, satisfactory - in $38,1 \%$ and in single cases - good exercise tolerance (in 14,3\%). The Ruffier test in children with CTD showed unsatisfactory and weak results in $56,0 \%$, more frequently than in first group $(p<0,01)$. Satisfactory results were in $32,0 \%$, and good results - in $12,0 \%$ cases of CTD. In the control group $55,0 \%$ of the children had satisfactory and good results, and $45,0 \%$ - weak and unsatisfactory. Tolerance for physical exercise did not correlate with anthropometric indicators, but $62,5 \%$ of adolescents with excessive body weight had unsatisfactory results of the Ruffier test.

Patients of all groups were physically inactive assessed in accordance with the IPAQ. The low level of physical activity (0-7,5 points) was in $52,3 \pm 2,9 \%$ during the week. Children with good and satisfactory exercise tolerance had average and high level of physical activity in $81,8 \%$. In children with $\mathrm{AH}$, both high $(55,1 \%)$ and low physical activity $(44,9 \%)$ were common. In the second group, high physical activity was observed less frequently $(48,5 \%)$, and 51,5\% had low physical activity according to the survey of IPAQ. Sports sections were attended by $25,0 \%$ of adolescents with $\mathrm{AH}$ and $33,0 \%$ of children in the second group. In control group level of physical activity was deficient in $61,1 \%$ of children.

There were no significant differences in exercise tolerance and physical activity. Physical activity level had a direct correlation with the result of the Ruffier test. Children with low physical activity were more likely to exhibit weak and unsatisfactory exercise tolerance.

When assessing autonomic response by the orthostatic test $47,6 \%$ of children had normal variant of vegetative response. In $29,9 \%$ cases was unsympathetic variant, in $5,6 \%$ hypersympathetic, in 16,8\% - hyperdiastolic variant was observed. Thus, $29,4 \%$ of boys with AH had a normal response of an autonomic nervous system. Unsympathetic responding was observed in $47,0 \%$ of patients, and $23,0 \%$ of adolescents had hypersympathetic and hyperdiastolic variants. Variants of excessive vegetative provision in $90,0 \%$ of cases accompanied a decrease in tolerance for physical exercises. Hyperdiastolic variant was determined in $44,4 \%$ of them.

Among children with CTD 63,3\% had a normal response to orthostatic body position. At the same time, $23,4 \%$ showed a weakening of autonomic support, and $13.3 \%$ of children had unfavorable types of autonomic support hypersympathetic and hyperdiastolic. The Marfan-like variant among the total number of patients with CTD-10,0 \%, Elers-like - 30,0\%, unclassified $-60,0 \%$. Unsatisfactory exercise tolerance was observed in all adolescents with Marfan-like phenotype and in $86.7 \%$ - with Elers-like. Children with a Marfan-like variant in $50,0 \%$ showed an unsympathetic variant of autonomic response, and a 50,0\% hyperdiastolic variant. Among patients who had an Elers-like variant, a normal response to orthostatic position was observed in $60,0 \%$ of patients. They have decreased exercise tolerance in $86,7 \%$ cases. Unsympathetic and hypersympathetic reactions were observed in the remaining $40,0 \%$ of children with this variant of CTD. Among children with the unclassified variant of CTD, 70,5\% had a normal response, 5,9\% were unsympathetic, hyperdiastolic and hypersympathetic in the remaining $23,5 \%$ of cases. Children with a normal variant of ortostatic response showed in $25,0 \%$ unsatisfactory, in $33,3 \%$ weak, in $33,0 \%$ satisfactory, in $8,3 \%$ good results of the Ruffier test. Healthy adolescents in $72,3 \%$ had adequate vegetative provision (normal variant of orthostatic test).

\section{CONCLUSION}

Almost half of the adolescents with both $\mathrm{AH}$ and CTD showed a decrease in the adaptive 
capacity of the cardiovascular system according to the Ruffier test. The most disadvantaged was group with CTD.

The physical activity and physical development of children affect the adaptive capabilities of a growing organism. Obviously, this is due to the fact that the children in group with $\mathrm{AH}$ and CTD were less physically active than children without myocardial pathology. At the same time, the presence of high blood pressure in adolescents is not an indisputable factor in reducing tolerance to exercise.

There is a decrease in the adaptive capacity of the cardiovascular system in differentiated variants of CTD - Marfan-like and Elers-like, as evidenced by the low results of the Ruffier test and adaptive types of autonomic activity.
The decrease of tolerance to physical loads in most adolescents with AH and CTD occurs against the background of the deterioration of aerobic capabilities and the violation of the autonomic activity, beginning of the formation of left ventricular hypertrophy.

Adolescents who showed the reduced results of Ruffier's test and had regular sports sections need change of a mode of training and further inspection.

\section{PROSPECTS FOR FUTURE STUDIES. AUTHOR CONTRIBUTIONS}

All authors listed have made a substantial, direct and intellectual contribution to the work, and approved it for publication.

\section{REFERENCES}

1. Gregg, E. W., Pereira, M., Caspersen, C. J. (2000). Physical activity, falls, and fractures among older adults: a review of the epidemiologic evidence. Journal of the American Geriatrics Society, 48, 883-893. DOI: $10.1111 / \mathrm{j} .1532-5415.2000 . t b 06884 . x$

2. Nystoriak, M., Bhatnagar, A. (2018). Cardiovascular Effects and Benefits of Exercise. Frontiers in Cardiovascular Medicine, 5, 1-11. DOI: 10.3389/fcvm.2018.0013

3. Benjamin, E. J. et al., (2017). Heart disease and stroke statistics-2017 update: a report from the American Heart Association. Circulation, 135:e146-603. DOI:10.1161/CIR.0000000000000485

4. Zakharova, Y. V. (2011). Small anomalies of heart development in children as a manifestation of connective tissue dysplasia Consilium Medicum Pediatriya, presented at the Russian collection of scientific works with international participation «Pediatric aspects of connective tissue dysplasia. Achievements and prospects», 2, 57-61.

5. Tian, D., Meng, J. (2019). Exercise for Prevention and Relief of Cardiovascular Disease: Prognoses, Mechanisms, and Approaches. Oxidative Medicine and Cellular Longevity, 1-11. DOI: $10.1155 / 2019 / 3756750$

6. Pinckard, K., Baskin, K., Stanford, K. (2019). Effects of Exercise to Improve Cardiovascular Health. Frontiers in Cardiovascular Medicine, 6. DOI: 10.3389/fcvm.2019.00069

7. Gisele dos Santos, Pegoraro, M., Sandrini, F., Macuco, E. (2008). Risk Factors for the Development of Atherosclerosis in Childhood and Adolescence. Arquivos Brasileiros de Cardiologia, 90, 276-283. DOI: $10.1590 / \mathrm{s} 0066-782 \times 2008000400012$

8. Martyniuk, O. \&Vilyanskiy, V. (2015). Assessment of students' health condition by indicators of adaptation potential, biological age and bio-energetic reserves of organism. Physical education of students. 3, 20-29. Retrieved from http://nbuv.gov.ua/UJRN/PhVSTSE_2015_3_5

9. Kelley, G. \&Tran, Z. (2007). The Effects of Exercise on Resting Blood Pressure in Children and Adolescents: A Meta-Analysis of Randomized Controlled Trials. Preventive cardiology, 8-16. DOI: 10.1111/j.1520-037X.2003.01224.x

10. Thompson, P., Buchner, D., I. (2003). Piña Exercise and Physical Activity in the Prevention and Treatment of Atherosclerotic Cardiovascular Disease. Circulation. 3109-3116. DOI: 10.1161/01.CIR.0000075572.40158.77

11. Allen, D. H, Puddey, I. B, Morton, A. R, Beilin L. J. (1991). A controlled study of the effects of aerobic exercise on antihypertensive drug requirements of essential hypertensive patients in the general practice setting. Clinical and experimental pharmacology \& physiology, 18, 279-282. DOI: 10.1111/j.14401681.1991.tb01445.x

12.Zhang, L., Liebelt, J. J., Madan, N., Shan, J., Taub, C. (2017). Comparison of Predictors of Heart Failure With Preserved Versus Reduced Ejection Fraction in a Multiracial Cohort of Preclinical Left Ventricular Diastolic Dysfunction. American Joural of Cardiology, 119(11), 1815-1820. DOI: 10.1016/j.amjcard.2017.03.005 
13. Flynn, J. T., Kaelber, D. C., Baker-Smith, C. M., et al. (2017). Clinical practice guideline for screening and management of high blood pressure in children and adolescents. Pediatrics.; 140:e20171904. DOI: 10.1542/peds.2017-1904

14. Alpert, B. S., Wilmore, J. H. (1994). Physical activity and blood pressure in adolescents. Pediatric Exercise Science, 6(4), 361-380. DOI: 10.1123/pes.6.4.361

15. Holovko, T., Shevchenko, N., Egwonor, A., Kwabena, B., Bwembya, C., Patience, M., \& Paul, O. (2019). Adaptive possibilities of the cardiovascular system in adolescents with non-inflammatory diseases of the myocardium, taking into account the functioning of the right ventricle of the heart. Aktual'ni problemi suchasnoï medicine, (3), 54-60. DOI: 10.26565/2617-409X-2019-3-08

16. Order of the Ministry of Health of Ukraine and the Ministry of Education and Science of Ukraine $\mathrm{N}$ 518/674 (2009). Regulations on medical and pedagogical control for physical education of students in general education educational institutions. Retrieved from http://news.yurist-online.com/laws/6323/ [in Ukrainian]

17. Bogmat, L. F., Mihalchuk, O. Y. (2010). Neyrogumoralnyie faktoryi v formirovanii sistolicheskoy disfunktsii miokarda u podrostkov s razlichnyimi variantami aritmiy. Zaporozhskiy meditsinskiy zhurnal, 12(2), 9-11. Retrieved from: http://nbuv.gov.ua/UJRN/Zmzh_2010_12_2_4

18. Rak, L. (2010). Faktoryi progressirovaniya hronicheskoy serdechnoy nedostatochnosti u detey s patologiey miokarda. Sovremennaya pediatriya, 2, 194.

19. Li, J., Siegrist, J. (2012). Physical activity and risk of cardiovascular disease--a meta-analysis of prospective cohort studies. International Journal of Environmental Research and Public Health., 9(2), 391-407. DOI: 10.3390/ijerph9020391

20. Nakaz MOZ Ukraïni № 802 (2013). Pro zatverdzhennya Kriterï̈ ocinki fizichnogo rozvitkuditej shkil'nogo viku. Retrieved from https://zakon.rada.gov.ua. [in Ukrainian].

21. Hagstromer, M., Oja, P., Sjostrom, M. (2005). The International Physical Activity Questionnaire (IPAQ): a study of concurrent and construct validity [Text]. Public Health Nutrition, 9(6), 755-762. DOI: 10.1079/PHN200589

22. Submission to the World Health Organization (WHO) on the Draft WHO Global Action Plan on Physical Activity 2018-2030. Retrieved from https://www.who.int/ncds/prevention/physical-activity/global-actionplan-2018-2030/en/

23. Booth, M. L., Okely, A. D., Chey, T. N. (2002). The reliability and validity of the Adolescent Physical Activity Recall Questionnare [Text]. Med SciSport Exercise, 34(12), 1986-1995. DOI: 10.1097/00005768200212000-00019

\title{
ТОЛЕРАНТНІСТЬ ДО ФІЗИЧНОГО НАВАНТАЖЕННЯ І ФІЗИЧНА АКТИВНІСТЬ У ДІТЕЙ $З$ НАЙПОШИРЕНІШИМИ СЕРЦЕВО-СУДИННИМИ ЗАХВОРЮВАННЯМИ
}

\author{
Штрах К., Рак Л., Шевченко Н., Одігбо Шалом
}

PEЗНМЕ: Серцево-судинна система бере активну участь в пристосувальних реакціях організму, а зниження функціональних можливостей серця погіршує адаптаційні процеси організму. Саме на цьому тлі формується артеріальна гіпертензія - причина фатальних кардіоваскулярних подій у дорослому віці. Порушення адаптації до фізичного навантаження має на увазі розвиток функціональних змін серцево-судинної системи. Метою нашого дослідження було визначення адаптаційних можливостей серцево-судинної системи підлітків з незапальними кардіоміопатіями в залежності від рівня фізичної активності. Було обстежено 92 пацієнта з артеріальною гіпертензією і дисплазією сполучної тканини, середній вік яких склав 15,4 $\pm 1,33$ року. Для вивчення толерантності до мінімального фізичного навантаження та її впливу на стан серцево-судинної системи у дітей був проведений тест Руф'є. Вегетативна реактивність центральної нервової системи досліджувалася за допомогою ортостатичної проби. Функціональний стан міокарда оцінювали за результатами ультразвукового допплерівського дослідження серця. В результаті дослідження було встановлено, що у дітей 3 дисплазією сполучної тканини чи артеріальною гіпертензією порушуються механізми адаптації, що супроводжуються ослабленням функціональних можливостей серця. Це відбувається на тлі зниження функціонування лівого шлуночка. Ці зміни супроводжуються зниженням толерантності до навантажень і порушенням вегетативного гомеостазу - недостатнім або надмірним вегетативним забезпеченням. Фізична активність і фізичний розвиток дітей впливають на адаптаційні можливості організму, що росте. Діти в групах з артеріальною гіпертензією та синдромом дисплазії сполучної тканини були менш фізично активні, ніж діти без патології міокарда. Підлітки, які відвідують спортивні секції та демонструють незадовільні результати проби Руф'є, потребують перегляду режиму тренувань і подальшого дообстеження. 
КЛЮЧОВІ СЛОВА: серцево-судинна система, адаптація, фізична активність, толерантність до фізичного навантаження, підлітки

\section{ИНФОРМАЦЯ ПРО АВТОРІВ}

Катерина Штрах, асистент кафедри педіатрії № 2, Харківський національний університет імені В. Н.Каразіна, пл. Свободи, 6, Харків, Україна, 61022, e-mail: shtrah@karazin.ua, ORCID ID: http://orcid.org/0000-0003-3563-0371 Лариса Рак, завідувач відділу педіатрії ДУ «Інститут охорони здоров’я дітей та підлітків НАМН України», проспект Ювілейний, 52 a, Харків, Україна, 61153, професор кафедри педіатрії, Харківський національний університет імені В. Н. Каразіна, пл. Свободи, 6, Харків, Україна, 61022, e-mail: larisarakdoct@ukr.net, ORCID ID: https://orcid.org/0000-0001-9955-2638

Наталія Шевченко, завідувач кафедри педіатрії № 2, Харківський національний університет імені В. Н. Каразіна, пл. Свободи, 6, Харків, Україна, 61022, доктор наук, провідний науковий співробітник відділу кардіоревматології ДУ «Інститут охорони здоров’я дітей та підлітків НАМН України», 61153. e-mail: natalia.shevchenko@karazin.ua; ORCID ID: https://orcid.org/0000-0003-4407-6050

Шалом Одігбо, студент 6 курсу медичного факультету; Харківський національний університет імені В. Н. Каразіна, пл. Свободи, 6, Харків, Україна, 61022, e-mail: kwinshally8167@gmail.com, ORCID ID: https://orcid.org/0000-0002-4314-312X

\section{ТОЛЕРАНТНОСТЬ К ФИЗИЧЕСКИМ НАГРУЗКАМ И ФИЗИЧЕСКАЯ АКТИВНОСТЬ У ДЕТЕЙ С НАИБОЛЕЕ РАСПРОСТРАНЕННЫМИ СЕРДЕЧНО-СОСУДИСТЫМИ ЗАБОЛЕВАНИЯМИ}

\section{Штрах Е., Рак Л., Шевченко Н., Одигбо Шалом}

РЕЗЮМЕ: Сердечно-сосудистая система активно участвует в приспособительных реакциях организма, а снижение функциональных возможностей сердца ухудшает адаптивные процессы в организме. Именно на этом фоне часто формируется артериальная гипертензия, известная как главная причина сосудистых катастроф во взрослом возрасте. Нарушение адаптации к физической нагрузке подразумевает развитие функциональных изменений сердечно-сосудистой системы. Целью нашего исследования было определение адаптационных возможностей сердечно-сосудистой системы подростков с невоспалительными кардиомиопатиями в зависимости от уровня физической активности. Было обследовано 92 пациента с артериальной гипертензией и дисплазией соединительной ткани, средний возраст которых составил $15,4 \pm 1,33$ года. Для изучения толерантности к минимальной физической нагрузке и ее влияния на состояние сердечно-сосудистой системы у детей была проведена проба Руфье. Вегетативная реактивность центральной нервной системы исследовалась с помощью ортостатической пробы. Функциональное состояние миокарда оценивалось по результатам ультразвукового допплеровского исследования сердца. В результате исследования было установлено, что у детей с дисплазией соединительной ткани или артериальной гипертензией нарушаются механизмы адаптации, сопровождающиеся ослаблением функциональных возможностей сердца. Это происходит на фоне снижения функционирования левого желудочка. Эти изменения сопровождаются снижением толерантности к нагрузкам и нарушению вегетативного гомеостаза - недостаточному или чрезмерному вегетативному обеспечению.

Физическая активность и физическое развитие детей влияют на адаптационные возможности растущего организма. Дети в группах с артериальной гипертензией и синдромом дисплазии соединительной ткани были менее физически активны, чем дети без патологии миокарда. Подростки, которые посещают спортивные секции и демонстрируют неудовлетворительные результаты пробы Руфье, нуждаются в пересмотре режима тренировок и дальнейшем дообследовании.

КЛЮЧЕВЫЕ СЛОВА: сердечно-сосудистая система, адаптация, физическая активность, толерантность к физической нагрузке, подростки

\section{ИНФОРМАЦИЯ ОБ АВТОРАХ}

Екатерина Штрах, ассистент кафедры педиатрии № 2 Харьковского национального университета имени В. Н. Каразина, пл. Свободы, 6, Харьков, Украина, 61022. e-mail: shtrah@karazin.ua, ORCID ID: http://orcid.org/0000-0003-3563-0371,

Лариса Рак, заведующая отделом педиатрии ГУ «Институт охраны здоровья детей и подростков НАМС Украины», проспект Юбилейный, 52 а, Харьков, Украина, 61153; профессор кафедры педиатрии Харьковского национального университета имени В. Н. Каразина, пл. Свободы, 6, Харьков, Украина, 61022. e-mail: larisarakdoct@ukr.net, ORCID ID: https://orcid.org/0000-0001-9955-2638 
Наталья Шевченко, заведующая кафедрой педиатрии № 2 Харьковского национального университета имени В. Н. Каразина, пл. Свободы, 6, Харьков, Украина, 61022; д.м.н., ведущий научный сотрудник отделения кардиоревматологии ГУ «Институт здравоохранения детей и подростков НАМН Украины», 61153. e-mail: natalia.shevchenko@karazin.ua, ORCID ID: https://orcid.org/0000-0003-4407-6050

Шалом Одигбо, студентка 6-го курса медицинского факультета Харьковского национального университета имени В. Н. Каразина, пл. Свободы, 6, Харьков, Украина, 61022. e-mail: kwinshally8167@gmail.com, ORCID ID: https://orcid.org/0000-0002-4314-312X 